\title{
Core Teaching Techniques in Basic Level: Issues and Challenges
}

\author{
Prem Prasad Sigdel \\ Principal, People's Friendship Academy, Kathmandu, Nepal
}

\begin{abstract}
The article is about core teaching techniques that happens truly in classroom. Classroom is the core place of teaching learning process so this article has focused on core principles of classroom only. The real problem starts from classroom having multiple perspectives to be solved. A teacher is the real experiencer of all those activities; his authentic experiences have been presented and discussed in detail. It presented the activities of a teacher that happens in 40 to 50 minutes' time with students in classroom. The real problem of a teacher in teaching can be solved with the ideas from this article. The main problems of handling class have been presented and discussed with adequate solutions. The description is detail in a constructive way that enhances the modern philosophy of teaching. The pros and cons of classroom management are presented in a vivid way. It aims to prepare a holistic teacher who will be able to handle class comfortably. The blanket approach of training has been challenged presenting the real problems from field and its solutions. The participants are school teachers, vice-principal, cocoordinators and principal so it's inclusive as well. A true situational analysis is the real flavour of this workshop that happens within a period. It recognizes the multiplicities of classroom aspects that the teacher need to deal in bounded time and space.
\end{abstract}

Keywords: class concentration, homework, classwork, innovation, core teaching technique, alternative punishment, reading, rereading

DOI: $10.7176 /$ RHSS/10-9-07

Publication date:May $31^{\text {st }} 2020$

\section{Background of the Study}

Teaching is a challenging job since it has relation with human faculty with diverse interests and motives. The fact is that there are many students in a classroom, they represent different social backgrounds, same course materials is taught for different minds, and it is duty of teachers to make students faultless in reading, writing and calculation (3Rs) at least. Teachers have the responsibility to improve personal behaviors and attitude instructing students in classroom. The microcosm of classroom experience is reflected to the macrocosm i.e. society. Some questions often rise: Who is your teacher? Which is your school? How do you pass or complete certain level? Don't you know only this or that? Or, don't you know this easy one also? All these aspects happen in classroom in a limited space and time, microcosm, and it deems application in the society, macrocosm.

IBRD report (2018) focused on teachers' training to promote active learning methods in schools. The students need much care these days as the time has changed and reading is independent of rote learning. Korpershoek et. al. (2014) presented an interesting research report that effective teacher can increase students $50 \%$ up. Ineffective school and ineffective teacher have contributed only 3\% achievement; whereas effective school and ineffective teacher contribute $37 \%$ of learning achievement. It indicates that effective teacher and effective school have improved students upto $87 \%$. An effective teacher can do 50\% alone so teachers' empowerment has been much valued. To address such problems a workshop has been organized to train teacher for better output from the classroom. A workshop is a kind of seminar in which small group discussion is initiated for a particular subject. It has been a creative project that helps in the development of skills and techniques. It needs intensive study with series of meetings, study, work and discussion. Such meetings assist in finding out solution of the problem and suggest measures to formulate work effectively. It helps in exchanging ideas with colleagues so that learning can be broadened sharing knowledge and ideas.

Principal, as a school leader, has played main role supporting and enhancing teachers through training and motivation programs, as teachers are the key propellers of the school (Day \& Sammons, 2016). The principal's role is focused as the school leader who can improve teachers' quality as well as school environment. A little effort can help to prepare classroom management plans if teachers and principals have felt it their responsibility. It helps to make classroom effective so that students would learn more to achieve the motto of education. The guidance that the teacher has implemented in the classroom influences the whole life of students. It has also been regarded as the lifelong learning of the children that they can apply in their life. Eventually it affects the society, nation and the world; so teacher is regarded as the guru of students. Hence improvement in classroom environment is the essential part to have better output of the students. When classroom is not effective, it affects the whole process of teaching learning process. Classroom has got limited time and space in which teacher should do many, many things or activities within limited criteria. The main motto is that students should have been able to grasp the matter delivered by the teacher. So it needs effective management from teacher's side to manage everything in spite of the limited time and space. 
Teacher is a prime factor of teaching learning process who has played key role in maintaining classroom environment (OECD, 2016). So teacher should be equipped with all sorts of knowledge, techniques, and skills to handle students with different backgrounds and interests. It's the duty of teachers to guide students time and again to make them more accountable towards set rules. The general classroom rules consists to respect teachers and classmates, raise hand before speaking or leaving classroom, not to play with anything, following directions, asking questions related to lessons, and to be positive as a whole. However, no technique has been effective like any medicine for pain. Unitary application of any rule is counterproductive for the teacher unless he is not aware about multiple techniques, skills, rules, and ways that can be applicable at the same time to take hold of the goal of teaching. Uninteresting teaching is a major problem of classroom management so teachers need to make it more fun oriented and relevant to the students' demand. The $21^{\text {st }}$ century teaching has forwarded from 3 Rs to 4Cs. The Cs includes communicators, creators, critical thinkers, and collaborators (Teemuangsai \& Meesook, 2017). The Case 1 below indicates a grave situation of 3Rs and 4Cs.

\section{Case 1}

Once I visited class 8 when the subject teacher was absent. It was English subject. I encountered a student in this class who had no reading capacity. When I asked to read he was assisted by other student. I felt so down in the dumps that the student couldn't pronounce even a word of two letters only. I was in confusion what to do for the student. Teachers didn't report me that he had such reading problem as he was new in our school in class 8. I also didn't believe that he had such problem of reading. Then I thought of an idea to make him read. I asked him to spell all the letters and asked other students to follow him. He would spell and others would spell and then pronounce, again he pronounced and others would repeat. The classroom is full of rhyme of the students' reading. I have taken video of such reading and shared it in a meeting just then. I thought that he would feel shame and counseled him and his friends as well. I asked other students to help him rather not to laugh at. I also asked him to come school regularly so that he would be involved in reading in the same way. I called the teachers' meeting and told them to follow the same style for his reading. I asked them to allow more time while reading. After some days he would be able to spell the letters well. Still he is in confusion in ' $j$ ' and ' $g$ '. I hope that he can be improved in the future.

The national level report of Nepal in basic literacy is quite depressing as there is poor performance of students in 3Rs. It is below 50\% even in class 8 also; it is extremely low in junior level (MoE, Nepal, 2014). The above Case 1 is a best example that pinched me a lot. It is supposed that going school means to get proficiency of 3Rs at least. Even uninterested student should have such proficiency because he has to encounter with such lack throughout his life if it can't happen in classroom. So the governments have put effort on basic level education for their citizens to get basic proficiency.

Teachers' mastery over subject matter, techniques of management and set rules in classroom have established trust among students. The students would be aware about the rule and its consequence at prior so it would be helpful for promoting teaching learning process. The main purpose of the classroom management should keep students on-task engagement to control disturbance. Similarly teacher should be punctual, managed, equipped with materials and active to perform activities in the classroom. Teachers need special techniques so teaching has been connected with art that is interesting as well as challenging. Teacher as Master has got mastery over everything who is an influential advisor or mentor for students.

It is an evident that teaching strategy has had direct link with students' learning achievement. The fact is that students believe their teacher by heart rather than parents or guardians in teaching learning process. The words, phrases, activities, style of speaking, doings and so on are influencing factors for students. The demanding fact is that all those skills need to be practiced in the classroom within limited time. There is the call for to establish "supportive, positive, and safe school environments [to] enable effective teaching and learning" (Hanover Research, 2017 , p. 3). Teachers must praise students' work or behavior not of their physicality which is the genuine nature of genuine teacher and a genuine comment. It doesn't matter whatever the qualities students have, teacher needs to assimilate with them so the flexibility of technique is a craft of an effective teacher. Thus teaching seems to be challenging and multidimensional containing various components (OECD, 2016). Teachers should be in proper dress; they should do everything skillfully; they should perform their talent; they should be compassionate; they should be model and inspirer; they should be judgmental; they should maintain their attitude; they must have social relation; they should have official relation; they should have reading habit; they should get knowledge from authentic source; they should get mastery over subject matter; they should have been familiar with the world events; they should suppress their emotion; they should remain patient and so on. Even more teacher should have necessary materials to teach lesson; they must have skill to prepare materials according to the theme of the lesson; they should have pleasant faces to attract students; they need to do timely decision of students' problems; they should have the knowledge of students' attitudes and behaviors; they should be aware about students' social and family background and behaviors.

Hence teaching is a unique job in which your shared ideas have been able to bring change in students and society. Teachers are the master of skills that 40 to 50 minutes of classroom is sufficient for them to perform 
numbers of activities. Students have reflected their personal and social manners along with their background. Their practices have reflected their family, social and traditional practices. So the understanding of teacher needs to be broad and exigent. The matter is that all those things should be done in limited time and space with mindfulness. They need to check students' books, copies, necessary materials, homework, arrange their position, listen their complain, pay attention to their experiences, and prop up their talent. They must read the text, let students read, look after them whether they have followed or not, answer their queries, control classroom, deliver their ideas, help weak students, address the queries of talent students, look after the spam done in classroom, be aware about cheating, assign homework and classwork, check homework and classwork. In spite of all those duties of pressure he must have smiling face at last.

IBRD report (2018) recommended three elements for improved leaning environment in school. They are "Assess learning - to make it a serious goal; Act on evidence - to make schools work for all learners; Align actors - to make the whole system work for learning" (p. 3). The crux of all these activities is classroom which is much joyful if teacher is aware about interesting facts and activities of students. There comes challenge and joyness together in the classroom where they have been dealing with innocent mind without vested interest. The cheating and spam that the students have played are transitory and artistic if it is taken positively. Teachers need to be aware about such facts and events to get bliss in the class. Unless teachers don't know the problems of classroom, he can't perform well rather it is an enormous burden in his career. Classroom environment must be student friendly where teacher should work as facilitator, mentor, and guardian. It turns into chores unless teachers aren't aware about constructive nature of classroom. So classroom has to be more practicable rather than vomiting some ideas which are the characteristics of a bad teacher (Sieberer-Nagler, 2015). It's better to listen students' experiences, practices and apply in the classroom that helps their creativity and students would feel proud of it.

Classroom management thus has put more value because of its technical nature of subjective matters. The occurrence and reflection of the classroom activities have much value to formulate classroom more innovative and motivating. It helps in formulation of the technicality of the classroom to make it extremely effective. Teachers can learn from the drawbacks and to deal class differently to make it dynamic. It is against the mechanical approach like going into classroom, make or let students read and write and assigning homework or classwork is an iterative process. On the other hand, bad teachers praise their 'self-image' and claim themselves as very good teachers of doing nothing (Sieberer-Nagler, 2015). The novice teachers have much problem structuring their lessons in comparison to the experienced one. It doesn't add enthusiasm for students so they remain passive and there is problem in class concentration, reading, doing classwork and homework. As a result, teachers would follow the way of capital punishment that is harmful to both parties. Classroom should be vivacious for students and teachers with new and creative ideas.

Students can learn if their homework or classwork is checked in front of them along with feedbacks. An effective teacher should welcome "feedback and praise handling mistakes, questions from students, and clearly structured lessons" ( $p$ 171). The comments that the teacher has given have to be realized or read by the students not to repeat next time. Only mechanical comments without feedbacks don't put any value for the students. Thus the involvement of teacher in students' activities deemed necessary and effective to solve the problem of underachievement. It seems quite difficult for the teachers to promote such activities; however that can be done with the interactions between teachers and students (IBRD, 2018).

The pros and cons of teaching learning process is much interconnected from home to school and vice-versa. It is like a mess that we can't find any proper solution of any style of reading or writing. Unless we can't identify the root cause of the problem we will always remain in muddle. The teacher would be in puzzle when they don't have proper guideline from school administration. Classroom can be effective with competent teacher who can weave thread to prepare a net together skillfully. An effective teacher can do such activities creating "safer school" which is free of violence and full of love and compassion (MoES, Uganda, 2014). Finding root of the problem is half of the solution that can be assisted by trainings and workshops. The mechanical aspect of teaching learning process has often been questioned as it has been teacher centered. However, student centered teaching is also defective due to messy classroom where the role of teacher is ignored. There may be the chance that talent student can grab more opportunities in the classroom and the weak may involve in misusing the situation.

On the other hand, the weak focused teaching may discourage talent students. Hence the paradox of teaching is much interesting and unsolvable. The responsible teacher can improve the environment of the classroom and make students, either talent or weak, satisfy to guide towards better output. So the training in 'core teaching techniques' seems necessary to make classroom effective and to have better output. It will certainly solve the puzzle or contradiction which teachers have felt. It will be a key approach in handling class in basic level teaching solving numerous problems mentioned above. The subsequent chapter is about literature review which helps in finding research gap or proves significance of the study. 


\section{Literature Review}

Literature review helps to set the agenda borrowing ideas from past studies. Its purpose is either to present gap or to find out the new area of research. Sometimes it supports the study or presents the other side of the study which we can take as positive and negative areas of research study respectively. However, it makes us clear about the agenda what we have presented analyzing pros and cons. According to the need of the study I have focused on the innovative aspect of classroom management in this article. So I want to focus on separate aspects in different subheadings.

\section{Class concentration}

Starting and handling a class is quite challenging as it has been the process of dynamism rather fixed mechanism. It varies according to the understandings of teachers, students, and the demand of situation. So it has taken several minutes to manage class properly unless the teacher isn't prepared about that (Kohler-Evans, 2013). Some teachers can begin with the revision class so that students can remember the lesson taught yesterday. It would help them to reflect their previous content and be ready to move for new lesson. Some teacher would divide the content into different sessions and manage time accordingly. Korpershoek et. al. (2014) advocate about effective classroom management that is essential for effective education. They said that teachers have played a key role in setting effective classroom.

Chaotic environment in classroom is much depressing to those who are talent and those who are the prosecutor Prevention first (2014) recommended that teacher should focus "on creating a peaceful learning environment that is comfortable, organized, engaging, and respectful for both teacher and students" (p. 3). The kids are kids in the classroom who try to disrupt classroom environment as they can. They have their own motto, though purposeless for teachers, and concentration that represents their social, economic, family and habitual matters. Some students may take interest in lessons taught and some of them would feel bored at the same time. The contradiction is that students do according to their interest whereas teacher wants to impose his ideas with the means of so-called teaching. The consequence is that teaching turns into 'teasing' unless there is no concentration.

The Honour Level System (2012) suggested forming different groups in the classroom and teacher can be an observer or facilitator for class concentration. On the other hand, Jackson (2004) argued that no teacher, either experienced also, can deliver message without creating peaceful and orderly classroom. Thus the teacher should organize students, space, time and materials to promote their learning. The goal of teachers is to make classroom effective and to create positive classroom climate. Learning depends on head and heart where fear has played negative role so children learn their teacher first (Sieberer-Nagler, 2015). Thus teacher's role is very much important in elementary school than in college level. The teacher needs in-depth understanding of subject matter along with maintaining concentration in classroom. Teacher needs to know the interest and styles of students so that the problems can be controlled along with the best of skill. Mostly the problems of unsystematic class are "discipline, students' motivation, handling students' social and emotional problems, little or no support from the parents, violence, working with special education or inclusion of students" (p. 163).

Johnson (2001) suggested 7 techniques for effective teacher to motivate students for concentration. Those points have oriented towards modern teaching learning process in which inclusion is focused more. He suggested forming limited classroom rules stating in positive terms. They should be less and effective so that students can understand clearly and well. He further suggested giving positive feedbacks to students as "praise, hugs, smiles, handshakes, nods, and eye contact" ( $\mathrm{p} 3$ ). It needs consistency while applying rules neither student can question about it and out-of-track. These rules can also be shared to parents or guardians to make them more effective. Coercive or punitive climate promote antisocial behavior for the students. Johnson emphasizes that positive as well as negative feedbacks should occur in equal frequency in classroom whereas negative feedback is more frequent by the teachers.

\section{Teaching, reading and rereading}

Reading has been hardly felt essential in pedagogical practices so the teachers lack such skills. The basic motto of teaching in junior level is to make students perfect in reading, writing and calculation. To promote reading we need to promote library especially book corner in a classroom which is lacking in Nepal (MoE, Nepal, 2014). Only $12 \%$ schools have got corner library that helps to build reading habit. The report further states that it needs optimistic understandings or ideas for teachers to solve problem of reading 'sub-skills'. Reading is known as subskill of the teaching part that hasn't been focused yet especially in developing countries. The report advocates that primary reading is "really low" which is "far lower than grade-wise expectations" (p. 4). It is same, quite depressing, in South Asian and other developing countries in the world. The report also claimed that "writing skills are much weaker than reading skills" (p. 4). We can realize the scenario that those students who can read would write excellently. The report further suggested some major problems in reading as follow: focus on teaching content more, not taught decoding, reading is not assessed, high disparity in reading levels in a class, no revision and remediation class for weaker students. The report recognizes listening and reading as foundational skills that need 
support from parents and community. The report suggested promoting parental reading program first to make students read well.

Jackson (2004) opined that only effective teacher can make students spell the word well which has been lacking in our classrooms. The report of NEGRP is evident for that. Wallis (2003) suggested assigning additional readings for the students to develop reading habit. Similarly, she has further instructed teachers to make students to collaborate reading with colleagues so that their learning habit can be improved as the want of teacher. Mathema (2007) emphasized to have availability of reading materials for the promotion of reading among students. He further argued that "seminars and discussions rarely take place and reading assignments, drafting term-papers, project work, and case studies are unheard of" (p. 54). Andersson and Lindkvist (2000) have presented the just opposite report rather than NEGRP in which teachers and students would do reading well in classroom. Students were satisfied and perfect in reading achievement. They claimed that "all the pupils repeat the difficult word in chorus. The lesson continues with the pupils reading the text aloud, the pupils take of their own free will initiative to read" (p. 42). According to their analysis there is nothing lack in developing four basic skills like listening, speaking, reading and writing.

\section{Alternative punishment}

Teachers have been assigned the responsibility of developing suitable behavior and morality in students. The most common way to deal with indiscipline is physical punishment that is ordinary for all teachers (MoES, Uganda, 2014). It means to make someone physically pain and to make them remain silent or quiet in classroom is the motto of instructor. Punishment for students can have two categories like corporal and emotional punishment. The report mentioned that physical punishment takes "slapping, smacking, punching or hitting with objects. It also involves pulling a child's ears or hair, forcing him to hold an uncomfortable position or compelling him to stand in the heat or cold"(p. 27). On the other hand, emotional punishment takes different forms like "shouting, yelling, name-calling, ignoring, embarrassing, shaming"(p. 27). Corporal punishment gets quick result whereas emotional punishment has late result. Though punishment gives some relief for the prosecutor but it has been more painful to those who have faced it. That has had negative impact in the future to those students. If teachers have adopted the right approach for discipline, that will stop the lengthening indisciplined behavior among students. Positive thinking leads towards succession or higher achievement whereas negative consequence leads towards doom.

Jackson (2004) commented children's behaviour using "the prefix dis: "disenchanted, disaffected, disaffiliated, disturbed and disruptive" (p. 1). He has rather suggested that teachers must make rules to support students rather to punish them. It means punitive environment has darker side in the mirror. He divided teachers into three categories as: authoritarian, indifferent, and laissez-faire. Among them laissez-faire teacher has the capacity to control students without any demand so reading can be improved.

MoES, Uganda (2014) report suggests that Positive Discipline (PD) can be an alternative to corporal punishment in home and school as well. The context of positive discipline can be enhanced from students' side. It has looked after the interests, characters, social and family relations of the children and treats accordingly. Positive discipline is a long-term solution of those students who have been indisciplined. It helps in developing selfdiscipline among students. The good aspects of students can be praised or reinforced whereas bad behaviors can also be suggested so that teachers can create good environment in the classroom. It instructs students to handle the situation in a calm, friendly, and respectful ways. Ultimately it has promoted positive decision making skills in teachers and students. The report further advocates that those teachers and guardians who have faced corporal punishment in their life would use it frequently as research suggested.

The concept of corporal punishment can't be overall solution to students as practicing by the teachers. They would follow such measures to satisfy their ego only; rather the solution is to develop alternative measures. Busienei (2012) suggests teachers to use rewards and counseling instead of punishment. The alternative punishment can have "to water, weed a school farm or fix what they have broken" ( $p$ 158). There should be rational understanding in such activities which shouldn't be exploitative or excessive. School discipline has two important achievements like ensuring "the safety of staff and students and create an environment conducive to learning" ( $p$ 158). The only pious motto of the teaching and learning can be achieved through caution and cooperation not being angry. He further stated that "punishment brightened the head but instead it reduces the child status" (p 158).

\section{Classwork/ homework management}

There is misunderstanding regarding homework that the students should do something new rather than the teachers taught. smartclassroommanagement.com (2010) suggests teachers to assign easy task rather it can be repetition of yesterday's lesson. Students should do homework themselves without the help of others so that they would increase interest in doing homework. The report further states that "homework is an agreement between you (teacher) and your students". There shouldn't be parental involvement in doing homework unless they aren't interested. Those 
who want to guide their children can be an added asset for the children. If homework is difficult it will be returned to the teacher that is wrong.

Mathema (2007) suggests the government authorities to have monitoring and supervision of homework for students. He has further recommended providing remedial classes for those students who need help in doing homework. His further recommendation is that students should be in the level of developing critical thinking themselves. In contrast the study of Andersson and Lindkvist (2000) advocates that pupils have done homework. They dared to ask teacher about the homework that they haven't done. When we compare the ideas of Mathema and Andersson and Lindkvist, it's better to follow the style of smartclassroommanagement.com in which homework shouldn't be difficult for students.

Learnersedge.com opposes that anti homework campaigners have had wrong concept. It supports that homework has positive impact on children as they engage at home without going out to play with buddies. Homework is more supportive to children because it engages them at home and helps to remind their classroom activities. However the amount of assignment should depend on their age or grade. Only creative teacher along with the parents can assign homework in such a manner that students wouldn't feel bored. Smartclassroommnagement.com advocates homework as an extension of learning of children. It happens like that the rules of homework are like the rules of games that increase the practice of the students. It further stated that the motto of homework should be remembering and promoting thinking rather than discouraging them.

The concept about homework for children varies among teacher, parent, student and administrator as more, less, hard and easy. There are some fundamental questions that the responsiveclassroom.org raises as follow:

1. What about the children who never do their homework?

2. What about the students who only do part of the assignment?

3. What about the kids who don't do it because there's no one around at home to help them?

The mystery of homework is unsolvable if the teacher can't work consciously. So homework is an agreement between these partners though it hasn't been mentioned in rules. Teachers need caution that should have been increased gradually. Mostly teachers have assigned same homework to all the students which is not good for those who don't have expertise. A teacher needs to be conscious regarding the management of homework and its bad consequences. Teacher is a facilitator not the dictator that parents want to make them. The report suggests that teacher should be "flexible and to individualize assignments" for students. It needs some more time and skill for the teacher to assign effective homework in differentiated classroom.

Students have varying abilities so teacher should understand the student first to assign homework. The report regards that "homework is the students' ticket into homeroom". Parents and schools have such conception that the homework not doing students should go to the "buddy teacher's classroom to complete it". If suggestion is taken from students there is high chance of completing homework at home. So it helps in the progression of children. Teachers and parents expect a lot from children doing homework. The report lists some expectations like "we ask them to follow directions, to organize their materials, to manage their time, and to work independently". It has been a high expectation of us from students. However they are far below these expectations so we need to comply with their needs and abilities. The next section is about methodology that tells about the process in detail.

\section{Methodology}

The principal of school has realized problem in classroom management especially for the newly appointed teachers. He organized a meeting of teachers to discuss the problem. Teachers have been encouraged to share their ideas in the meeting for controlling students and engage them effectively. As a principal I have keen interest in promoting innovation in teaching and these meetings have been oriented accordingly. The time is too short in the meeting and the detail discussion of the issue is deemed necessary. The principal has identified the issue well and discussed with the core team like vice-principal and coordinators. They also agreed about the problem in classroom management to promote reading. The principal has taken different points and divided them into different subthemes so that the detail discussion of the issue is possible. Various points have been noted incorporating the classroom activities done by the teachers. Some points are independent and some can be incorporated with another if they have similar or dependent meaning.

Accordingly four main sub-topics have been identified dividing the 40-50 minutes' classroom time. The principal has discussed it with different teachers with the purpose of improving the sub-topics. It's the duty of principal to be "collegial, considerate and supportive, listening to teachers' ideas, and generally looking out for teachers' personal and professional welfare" (Day \& Sammons, 2016, p. 17). So different ideas have been incorporated and sub-categories have been done time and again taking the advice of the teachers. The following Case 2 has supported the motive of the principal.

\section{Case 2}

I have been the head teacher of the school for seven years. I thought to make the school more popular in quality education. Though there are various definitions of quality education I have set the aim to make students proficient in reading, writing and numeracy. Mainly I have been focusing on Primary grades as they indicate 
the future goal. So I have been focusing on teaching learning process of the students rather than other co and extra-curricular activities. I have seen the scholarship demanded by different organizations with certain percentages mentioned in their mark sheets rather than other capabilities. They announced to send their testimonials first; then they are said to be called on interview. Their talent is first measured by the marks in mark sheets. On the other hand, the problem of reading, writing and calculation is too poor of the most students. Thus I have the motto to improve that rather than running after propaganda. I have instructed all the teachers accordingly. They should concentrate on the students, their reading, writing and numeracy. The senior classes should have focused on the concept along with 3 Rs in their classroom. I have been encouraged searching innovation in teaching learning process so that no child is left to read. The national report regarding the proficiency in $3 \mathrm{R}$ is so depressing which is lower than $50 \%$ even in class 8 also. At least I thought to achieve such proficiency in my school as a responsible citizen. So I have always oriented innovation related to the promotion of 3Rs in my school.

The principal has thought about the time and venue to make it more effective and got approved from the school management committee. A resort has been chosen for workshop cum refreshment program. The teachers have also been consulted if they have chosen any better venue according to their interest. The administration values the involvement of teachers in decision making as they are the pillars of school. Four groups have been divided in equal numbers as there are four sub-themes of the workshop. A coordinator of each group has been chosen. All the teachers are asked to give possible suggestions of each issue to each coordinator. The points have been collected and written together dropping repeated points so that all of the ideas have been incorporated.

A pen and diary is given for each teacher as well as chart papers and metacards have also been given to each group to prepare for the workshop. The groups can note the points in their diary apart from the collection from colleagues. The coordinator has been given a special responsibility to make the program more effective. The meeting of the coordinators happened frequently with the principal regarding the preparation. They have been encouraged to prepare the paper and to lessen the time of workshop; so the time for refreshment can be increased. The work progress is highly enthusiastic as it has been followed and guided by the principal with cooperation and collaboration of teachers. The principal would take advice of all the teachers, if possible, to have any kind of decision as teachers have been handling the class not the principal.

Such type workshop, different in theme, had already been organized so the old teachers have such experience whereas some new teachers have been raw to it and experienced teachers assisted them. The four sub-themes of the workshop are as follow: Class Concentration; Teaching, Reading and Rereading; Alternative Punishment; Classwork /Homework Management. It has been incorporated under "core teaching techniques". All the groups have prepared it well till the day before the workshop. The enthusiasm of the teachers has increased so much that they have done much innovation to find out the tools for their topic. The principal has given frequent suggestions to those groups who have problems. After suggestions they have felt quite charm and the work was excellent.

There are altogether 30 teachers. In a group, level wise teachers have been divided equally. There are three levels of teachers such as Pre-primary (Nursery, LKG and UKG), Primary (class 1 to 5) and senior level (class 6 to 10). They have been divided equally in a proportional way. The principal has formed such group as there would be the mixture of ideas of different levels. Mostly such teachers represent their level along with their practices and experiences.

We departed towards the venue early in the morning at 7.30 am at the very day of workshop. The time schedule has already set for the preparation, presentation and refreshment.8.30 am to $9.00 \mathrm{am}$ is breakfast time; 9.00am to $10.00 \mathrm{am}$ is preparation time; $10.00 \mathrm{am}$ to $12.00 \mathrm{pm}$ is presentation and comment. Each group got 15 minutes time for presentation and 15 minutes for comment. The presentation and comment group have been fixed by lottery system. Group A's presentation should be commented by group B; group B's by group C; group C's by group D; and group D's by group A. Vice-principal has taken 15 minutes presentation before the starting of group presentation. The presentation has been facilitated by the principal and one of the education officers has been given the responsibility for evaluation. The education officer is also a trainer and he got interest to involve with us due to personal relation. It has been decided at the venue, to increase the sense of competition, to give a surprise gift for the best group.

The groups stayed at the round table and prepare their manual presentation well. They have been given different colour-markers and metacards to enlist their ideas. All the groups put their best effort and made the papers well decorated. The decoration has been improved well than in the first workshop as they have been used to for that. The principal and vice-principal have assisted them a lot in case of ideas and matters. Mt. Everest group prepared about classroom concentration; Saipal group prepared about teaching, reading and rereading; Annapurna group prepared about alternative punishment; and Machhapuchchhre group prepared about classwork/ homework management. Different groups prepared their presentation thematically which was stuck on the wall and explained for the spectators.

Different groups presented well and the comment was also systematic which had been facilitated by the principal. The groups have presented their papers by choosing their own leader either by the coordinator or others. 
They have used either English or Nepali language or both. After presentation and comment other groups can ask questions if they want to be clear. The program is becoming so systematic that all the participants have been enjoying a lot. Group B or Saipal group was declared best among the best. At last an evaluation form was filled up about the outcome of the training. Finally the education officer had presented 1 hour's motivational Power Point after lunch at 12.00 noon.

Breakfast at $8.00 \mathrm{am}$, lunch at 12.00 noon, snacks at $2.30 \mathrm{pm}$ and lunch at $5.00 \mathrm{pm}$ has been served. Time schedule is followed well, however, there is no such overlap on the allocated time. After workshop refreshment program happened well then we returned back to school at $6.30 \mathrm{pm}$.

\section{Data Discussion}

The data discussion has been enlisted as per the presentation of the teachers. There is no change at all except making it clear. Teachers have listed various points which are listed below under the heading of different groups. I followed Korpershoek et. al. (2014) that "teacher training programs should provide [...] teachers with a large "toolbox" of CMS from which they can pick and apply particular strategies when necessary" (p. 8). The CMS stands as classroom management strategies; we have done same as mentioned above. The ideas of different groups have been listed below serially.

Group A is named as Mt. Everest group which has taken the responsibility to prepare tips for class concentration and to present in the workshop. It has been important to draw attention of all the students after entering into classroom. It has been the initial as well as all time process of limited class hour. So it needs more conscientious technique for teachers to make classroom attentive. Unless the classroom isn't silent, teacher can't perform his activities that may hamper the goal of the class. The group listed their ideas making the picture of classroom along with the picture of teacher and students. It has been framed in different style and pictures. The border decoration is also attractive. They have used two languages i. e. English and Nepali. Some of the teachers are from English background and some of them are form Nepali background so there is the mixture of two languages. The use of two languages doesn't hamper the understanding as it has been translated into both languages

They have listed 26 techniques/ tools of class concentration that the teacher can use. They are listed below: active and energetic posture, singing rhymes, doing physical training (PT), dancing or doing any fun activity, change the level of voice, showing fascinating things to students, producing sounds of different animals or birds, distributing sweets, being silent in attentive position, sharing own experience in the form of anecdote, producing unexpected sound, telling to be quiet, asking student to show their talent, asking student to come at the front and do any mimics, entering with smiling face, moving through the whole class looking at students, telling interesting facts, making students clapping hands, cooperating with unexpected students, making fun, cracking jokes and telling short stories, interacting with students, begin with the thought of the day, presenting new lesson in an interesting way, asking questions about yesterday's reading, start biography of any social personality, eye contact to all students. The above techniques are very much meaningful for a teacher who wants to learn the techniques of class concentration.

Group B has been named as Saipal group. They have taken the responsibility preparing presentation for teaching, reading and rereading. The teacher would teach first, then he asks one of the students to read and others to follow; or the teacher would read and students would follow. The students should have encouraged rereading, neither they would have forgotten by the next day. Hence teaching is waste for the dutiful teacher. The reading process should have line wise or paragraph wise in which all the students' involvement is compulsory.

This topic has been mixed with three themes like teaching, reading and rereading. So it has included three different thematic points, however they come together in the process of classroom handling. The group has categorized six themes and made presentation in hearts at the centre and square, rectangle and circle by the side. The decoration is very attractive. They have used English language only in their paper. Their techniques have been listed in 15 different points. They are as follow: discussing about the topic, explaining topic first, tell any students to read and others would follow, two of the students read and others can follow and check their mistakes, telling students reading line by line pointing by finger, do cross checking by students and teachers as well, take oral as well as written dictation, addressing their curiosity, engage them in writing, do mimics (caricature) while teaching, asking questions by teachers, encourage students to ask questions, assigning classwork and homework, doing eye contact. The techniques are not systematically arranged as classroom activities have not followed synchronic structure. The teacher is free to apply it in his own way.

Group $\mathbf{C}$ is named as Annapurna group. They have taken the responsibility of preparing presentation about alternative punishment. This topic has been taken somehow negatively. Some naughty students have disturbed class very much so the teacher needs to be equipped with such techniques. They have even disturbed the whole class so it makes difficult to handle class comfortably. Since capital punishment is discarded in the classroom, alternative punishment has been put forward as a solution of class disturbance. This group has presented it in points as they have only one topic. Paper border has been decorated well and different pictures have been made against of capital punishment. 
The ideas have been listed below as: ask students to complete assignment during lunch time, communicate with parents, reduce homework and increase classwork, deduct points for late assignment, make students clean classroom or school premises, calling by the name, using critical language like scolding, giving attention to the naughty one, make them do extra activities, refer to coordinatior, vice-principal or principal, be kind to weak students, counsel to poor students, write their name on board, make them stand at the front of classroom, giving surprise gift, changing their seat, make them pay fine or penalty, ask them hands up and stand up, involve in social work, ask them to do up and down (telling more and doing less). The group has presented it with numbers of possibilities that don't disturb the code of child rights. The teacher can use them as tools not means for class concentration to run class smoothly.

Group D is named as Machhapuchchhre group. They have taken the responsibility of preparing presentation about classwork and homework management. They have presented their work dividing into 5 sub themes. Their paper decoration is also attractive. Their points have been listed in 14 points. They are as below: reading lesson, combine reading, group discussion, make creative questions, revision of previous lesson, drawing or presentation, quiz, game or refreshing activities, doing exercise, handwriting (one/two pages), project work related to lesson, drawing, assigning any social activities, free writings (essay/ biography/ diary/ travelogue). Homework has been a popular word for students, parents and teachers. The students consider written as homework only and reading is no-homework. It needs rethinking regarding reading homework that should have been realized by the parents as well.

\section{Data Analysis}

Data analysis is an important part of the research article. It is important in two ways: first it has tried to approve the findings with theories and literatures. Second, it analyzes the data along with the motto of the research and data itself. I have analyzed the data of this workshop along with the sub-themes divided for discussion.

Case 3
This workshop has been the outcome of 15 years teaching/ learning experience of mine. I have been working
as teacher, academic in-charge and principal respectively throughout my career. I have been seeking innovation
in teaching and to improve the learning standard of students. Classroom activities have greater influence in
teaching learning process. I have realized much problem in reading, writing and numeracy. The admitted
students from other schools in the new academic session are too much weak in reading. So I have committed to
improve reading skill of those students. On the other hand the national level literacy achievement of students is
also quite low that pinches me a lot. Another workshop had also been organized in which teachers' involvement
was active and they depicted much improvement in teaching students. In such workshop pre-class preparation,
during class activities and after class activities had been discussed. I wanted to go to the depth of innovation
and chose "core teaching activities" as its topic. It would be helpful for novice as well as experienced teachers.
The class time of $40 / 50$ minutes has been divided into four sub-topics and solutions have been sought minutely.
Different ideas have been presented by different teachers which are seen insignificant yet greater value for
innovative teaching learning process.

\section{Class concentration}

The effective teaching has connection with management and motivation of the teacher in classroom which can be possible with training. Teaching is complex yet interesting job which has relation with human mind and heart. It is quite challenging to control class of many students and to handle them to get the basic aim of teaching. Students are of various interests with different social and economic backgrounds so their priority is different. Teacher should address all those issues in the classroom at a limited time. The teacher who is perfect in subject matter is not sufficient rather he must have the techniques of managing classroom. So teacher should be multidimensional who could control class and deliver the education what he has been planning (OECD, 2016).

Teachers' classroom management strategies have contributed much on decreasing behavioral problem in classroom (Korpershoek, et. al., 2014). It emphasizes that teacher is the prime element of teaching learning process so he can do anything for the promotion of students' learning. Nowadays, we can feel a great change in classroom along with the development of new era and the demand of it. Rather than enforcing the ideas, teacher can take ideas from students and apply in the classroom. Or they can use some modern means and ways to attract attention of the students.

According to a report by the National Union of Teachers of USA "more than a third of teachers experience disrupted lessons as a result of misbehavior and that half of them believe that school discipline is a greater problem"(Sieberer-Nagler, 2015, p. 164). We can realize the problem of indiscipline in schools where teachers alone can't control it. The indiscipline of students disturbs the proceeding of the lesson. The fact is true so that we need to train teachers related to such issues. These days there is no chance of selection of students nor can we expel any student blaming his behavior. It is the right of the child to get education according to his interest. Rather 
than blaming child we need to find out alternative solution of class concentration. It is more precise decision of the policy maker and school administration.

It has been becoming a great problem these days when there is Education for All (EFA) goal to educate all the children. Moreover, Sieberer-Nagler (2015) emphasizes that novice teachers spend 30 to 80 percent of time addressing students' discipline problems in their classroom. Similarly another report of the American Federation of Teachers (AFT), presents that 17 percent of the teachers lost their four or more hours of teaching per week due to disruptive students and 19 percent lost two to three hours time per week while managing concentration. It is evident that the problem is genuine and it needs proper solution on time. Only teacher can't do it if there is no help from school administration. The Honour Level System (2012) suggests having constant eye contact to those students to keep in line. Instead of only one or two techniques the workshop has presented numbers of techniques that the teacher can apply as per the situation.

Mostly the novice teachers have class concentration problems as they are raw in teaching. Not only that the experienced teachers have also problem because they don't use alternative techniques rather they threaten students of getting legacy of old teacher. The complain about students and their problems have come when teachers don't have techniques. Rather than threatening students they need to take help of the techniques listed above. The socalled experienced teachers have called themselves as more qualified and they don't circulate throughout the room; neither have they engaged students properly. They use lecture method which doesn't confer enthusiasm to the students. These indifferent teachers have praised their self-image and stay idle in classroom (Jackson, 2004). Such teachers would have no interest in teaching rather they kill the precious time of students and be the source of fear and boring for students.

Indifferent teachers have been limited in parochial techniques so that the students become headache to them and vice-versa. Unless teachers don't learn techniques, classroom would be a mess of students and the goal can't be achieved. Effective teaching needs preparation for teachers before going to the class to prepare necessary materials. Prevention first (2014) presents some disturbing activities like "students wanting to dominate discussions, students who call out answers or don't wait to be called on, to the students who hum, click pens, and can't sit still" (p. 8). It happens due to the ineffective teacher who stay at a place, ask students to read only, don't engage students at all. On the other hand, students also disobeyed such teacher who is idle in classroom. So there is problem of concentration and teachers would complain instead.

The teacher without techniques would use his emotion to make students scary. So students would be physically punished which is defective to teachers and students both. The participants have listed twenty six different points for class concentration in which teachers can apply any technique taking the context of their classroom. It presents us the glimpse that no technique is unique all in all. So Sieberer-Nagler (2015) compared teachers as the conductor of orchestra and the class is orchestra in which different instruments have been played to produce music. Classroom climate is the spectrum of social, emotional and physical aspects that enhance students' growth and behavior. An effective teacher can only manage such orchestra neither it would be a mess of maze.

Motivation increases students' participation that matches with the tasks assigned to students with their abilities and interests. Teacher is the motivator in classroom so he must have conscientious decision to lead students towards positive learning environment. An active teacher having multiple techniques can only handle such class. The poor classroom management, if not corrected on time, causes "in a lower rate of academic engagement in the classroom" (p. 164). Hence we need a successful teacher who can evaluate the situation and use appropriate strategy to control students (Jackson, 2004).

Citing the causes of classroom disturbance, Prevention first (2014) has suggested some techniques like teacher can stop the lesson, pause and make eye contact so that students would keep quiet. If some students are quite disturbing, teacher can discuss after class alone to instruct him/her to follow rules. It helps greatly to understand the students' point of views since they are the main partners of the classroom. Teacher is the main leader or facilitator of the classroom to take it towards right direction. Class concentration is the first and foremost technique of any teacher who wants to deliver his message well in classroom. The students would pay respect those teachers who have such techniques. Threatening isn't the solution these days rather it has more negative effects along with the development of rights and teaching philosophies. The matter is that punctuality of the teacher and his caring nature to the students has put more value in class concentration and controlling of students. Sincerity pays overall for teachers and students not superiority.

For class concentration teacher should walk around the classroom and communicate regarding children's learning behavior and progress. Mistakes are the essential part of learning; so the mistakes done by the children can be corrected with positive feedbacks. The expert teacher learns from errors so that he can get even more trust from students. Hence learning climate needs to be peaceful, cool, systematic, managed and pre-established. 


\section{Teaching, reading and rereading}

Teaching is a common word, in this article, it's better to understand in a limited sense, which teachers do in classroom. It's a broad term that manages everything to disseminate learning to all. Apart from other things like writing, explaining, assigning homework or classwork, I have tried to focus on reading and rereading. Writing and explaining have already achieved in our school so that our orientation goes towards reading. However, reading and rereading is closely connected with writing and understanding as well. The word reading only doesn't work well so we have added 'rereading'. "Words fly, writing remains" is a Spanish proverb; indicates that once reading is not sufficient. Thus modern teaching technique has focused on iteration, not rote learning, of any subject to remember well.

Sieberer-Nagler (2015) argued that "students are not sponges and cannot immediately "absorb" new information" (p. 167). Thus there is necessity to have rereading class in our classroom. The metaphor of sponges is quite fit here as it has been an irony for indifferent teachers. So we have mixed the topic rereading along with reading. Most of the students would have forgotten "once-reading" lesson. So we need to concentrate on rereading the lesson to make them proficient in writing. In other words, reading is a repetitive process, different than writing, which is related to mind and heart whereas writing is the work of hand. The limited course material is repeated throughout the year time and again; still students seem much weaker in reading so we have focused on rereading in classroom. The participants have suggested many, many techniques which are applicable to promote reading in classroom.

IBRD (2018) report pointed out that "education systems are often poorly aligned with learning goals" (p. 170). It is evident that teachers need training and classroom preference is more valuable. According to a report by MoE, Nepal (2014) reading achievement is quite depressing and miserable in almost all grades. The report identified that lower grade writing is also quite lower than reading. However, our school has already achieved success in writing so we don't focus on it. The Case 1 presented above is also a good example of poor reading achievement. The workshop suggested various reading techniques along with teaching to be applicable in classroom. It is from the perspective of the bearer in the classroom. The report suggested that teachers need to circulate throughout the room inspecting the activities of students while engaging in on-task activities. Sometimes the teacher can offer incentive to the students to make them read more. The incentives don't mean the costly one it can be of anything which is available at the time such as clapping hand to those who have read well. Only a little thing like praising can encourage them to read even more. It's better to do some refreshing activities for students to promote their reading like sharing with each other, stand up, and one can ask others like pair reading.

Reading with colleagues can develop new understanding by the students in classroom so the teacher need to separate more time in reading (Sterling, 2003). It may develop sense of competition and students learn more along with peers. The communal activity in classroom is more important and fruitful than isolated reading. On the other hand, teacher and guardians have high expectations from their children. It is better to start from basic level that is applied in the classroom by the teacher. Thus students need support from teachers first, then from guardians to meet such challenges in their life. Little ways can enhance for high expectations in pupil that can happen in classroom or school only. MoE, Nepal (2014) report mentioned that reading is known as "sub-skills" only so that teachers have no focus at all in it. The report further suggested giving half of classroom time for reading only. In my experience also we need to separate at least half of the time in basic level for reading. These days students have no habit of reading at home due to lack of parents' time and uneducated parents who can't help their children in reading. Some children don't obey their parents in such process.

The concept of this topic in the workshop is that, rather than making students aware about various subjects, we need to promote reading. It would be fruitful to do hand-in-hand in national goal of reading achievement practically. In primary level, reading and rereading is much important rather than teaching. We can turn such teaching into reading, writing and numeracy only. The problems identified in the literature review of this article by NEGRP are more relevant that the focus has been diverted towards completing course bypassing students' reading skill. The Case 1 is an example of such poor class management regarding reading by the teachers which will continue till the end of school life. Mostly students have problems in reading well and to deal with different and difficult words; so reading is must. Some of the schools have implemented DEAR program for reading. It means Drop Everything and Read in their schools. They have separated limited time in their school which is not so effective as it has less than 15 minutes for limited time only. They separate certain time when students and teachers should read whatever the subject they have in their hand. The purpose of this rereading is to go to the root problem of the reading of each subject. According to this program, even mathematics is also included in reading in which students can pronounce either numbers or formulae or definitions. While reading, students should go throughout the page from top to bottom ignoring the fact of over-reading.

Teacher is the craftsman of classroom management who can only make classroom enjoyable. It's the responsibility of teacher to make classroom achievable. Children rarely like the subject matter they have been taught however it is the reality that they have to face in their life. It is the duty of teacher to concentrate on weak students mostly giving some more time. According to the motto of the workshop all students should have achieved 
reading goal in the future. The administration has set the aim to achieve such goal of reading in the next academic year as it has been started this year. Additionally, writing skills has got $100 \%$ achievement in this year which was started last year. It's quite shameful that grade 8 student has no reading skill at all. This experience led us to think innovatively. It increased tension for teachers when presented in the meeting as responsible persons in education sector. The process is going on to solve the problem of case 1; eventually it will be successful in the future.

\section{Alternative punishment}

Punishment in teaching learning process is not a good word as it has relation with prosecutor of law. Broadly speaking there are two kinds of punishments used in academic institutions: physical and psychological. Within these two categories teachers give various kinds of punishment to students. Either physical or psychological, punishment doesn't help either party which is not good in school. However the use of punishment is often seen and heard. It is protested as much as it has been practiced in education. Physical punishment is seen and it attracts the attention of all the rightists whereas psychological punishment is still hidden that needs detail understanding or research. Concerned persons or authorities have never tried to solve the problem sitting with teachers and students; it is rather advocated with vested interest. However the root of such problem is grave to both parties.

In this workshop participants have tried to find out the solution of such problems seeking alternatives. It seems that punitive environment is not possible to ban even in most peaceful situations unless we don't find alternatives. Korpershoek,et.al. (2014) recommended two categories of solution as preventive and reactive strategies. According to preventive strategies teachers establish rules at first; whereas giving punishments or warnings are known as reactive strategies. This workshop has tried to find out solution from preventive strategies so the teachers have found out various solutions of a problem. Day and Sammons (2016) suggested that head teachers have the responsibility to minimize students' misbehavior creating peaceful environment in school. They further suggested that head teachers should create highly valued condition for work in school. The workshop has done exactly providing the resources for the teachers for class control.

The youngsters want to be addressed by name and they want praise what they have done irrespective of the result. Teaching learning process wants positive feedback, though it is bad work, which is against beating or rebuke or defamed. Teachers can praise students' work or behavior not of their physicality which is the genuine nature of genuine teacher and a genuine comment (Prevention first, 2014). Mutuality is another aspect of emotion that brings teacher and student together. So it helps in maintaining discipline in classroom well. Sieberer-Nagler (2015) observes students' characters from two perspectives as internal and external. Teachers try to control external character whereas the problems lie in internal character so the punishment is given to those students. It's good to identify the cause before giving punishment which has root in internal character.

The radical side of alternative punishment is to let students free of reading and writing how they like. We can find some examples of such radicalism while reading Gijubhai and Paulo Freire. However we need systematic classroom unlike their utopia. Disturbing environment has troubled others in classroom so the job of teacher is also in risk. The often heard comment is that "teachers don't teach well". It is a popular lip service to those who want to raise radical questions but they don't think where the problem is. This workshop tries to find out the solution of such complaint. In higher level, teachers punish students reducing marks in practical or in written examination. They would treat students rudely; it's psychological punishment. In school level, where the result is obvious to the parents, it can be crystal-clear from achievement of the students in 3Rs and 4Cs. Teachers should make students read and write as they have been under direct supervision by parents and school administration.

A possible solution from alternative perspective is to create community and engagement in classroom by making groups along with students' interest (Hanover Research, 2017). The sense of possession or ownership among students can control them internally. Such system has been regarded as best alternative for misbehaving students. Sometimes we can make leader of the class for those who have done much movement. Jackson (2004) stated that "student behavior change through "best practices," and staff behavior change through systems" (p. 7). It needs teachers' preparation, before the beginning of the classroom, so that best practices are possible. In other words we need to engage them frequently with constant praise and feedback.

Learning is for change in behavior that can be cognized as improvement in dealing, classroom contexts and social acceptance. Hence classroom context has influenced the social recognition of the students that is looked after with the improvement in behavior not physicality. Thus punishment only doesn't lead towards succession or improvement in behavior. Hence, the alternative of capital punishment is positive discipline (MoES, Uganda, 2014). Teachers need to use such techniques instead of physical punishment. The workshop has presented numbers of alternatives of physical punishment which are really creative and worth following. We shouldn't punish students with stick or using any physical materials rather we can assign extra works which add value in learning. So the motto of alternative punishment is to provide creative and constructive ways of dealing with students. The workshop has also been able to find out the solution of such problems. Moreover, the concept of alternative punishment should be "child-centric, placing at the heart of every interaction the best interests of the child" (p. 28). 
The next alternative solution of indiscipline is to expel students at the middle of the session or fail them at the last of the school year. It's not justice as the participants realize and we have committed to improve the quality from its root. The motto of workshop is to find out the solution of the problem not putting it aside. I have intention that there shouldn't be the selection from the entrance exam rather the admission process should be first come first basis. Workshop provides teachers important tips to deal in classroom so that no student is weak and useless. At least students would be able to achieve the basic motto of teaching i.e. 3Rs. In other words, it would be a high satisfaction to those teachers who want to make their students well. So teaching seems challenging job in these days because there is compulsory education system or no child is left behind school. If there is selective process from entrance examination also, it won't be solved like a magic. It needs joint effort of effective school and effective teacher to achieve such goal (Korpershoek et. al., 2014). If we have taken the responsibility of the students morally, the job of schools and teachers should make their students read well.

Poor quality of education services has been identified as a barrier for children staying in school, attending regularly and learning effectively. This is exacerbated by extensive use of corporal punishment and other forms of violence by teachers to discipline students. In order to eradicate harmful punishment in schools, it is vital to support and equip teachers with knowledge and skills to promote positive environment in the classroom that encourages good behavior. Teaching and learning needs to be inclusive, child centered and activity based. It should help in the development of positive discipline rather than harmful punishment. Teachers need support in managing classes through positive behavior and capacity building as alternative forms of discipline. Practice has shown that while focusing on positive techniques, participants move towards their own positive, creative state of mind; hence the tendency to justify physical punishments begins to fade (MoES, Uganda, 2014). Such an attitude would automatically displace punishments.

Take for example, children who are noisy or disrespectful in class. They may behave like that as they do not feel accepted by their peers. They are feeling vulnerable and insecure in that class so they are trying to make themselves look brave and strong. It's time for teacher to realize that the behavior is not the child's fault; he needs support rather than punishment. Alternative punishment is thought to be a better solution by the participants for better class concentration, reading and writing. It helps teachers to develop alternative tools rather than harassing students coming to school. It has positive aspects that every child is present in classroom for the sake of teacher. We need to tackle and find solution of the problem rather than escaping from it. So the motto of alternative punishment can be the key to solve such problems. Most of the alternative solutions of the workshop are creative; however some are physical but they are unlike corporal punishment. Teachers can apply them selecting the reliability of the situation.

\section{Classwork/ homework management}

This is the last topic of workshop presentation; as per the process of class also, classwork and homework come at last after other themes. Classwork and homework, in a blanket approach, are of three types: reading, writing and project work. Reading and writing are quite common classwork or homework in most of the schools. Some schools assign project works that need some more time and extra materials to prepare. So it is given mostly for some weeks or fortnightly or for a month's period. However the duty of teacher is to remind students time and again till the completion of it.

Effective teacher is conscious regarding the homework assigned to the students. The motto of homework is not to scare the students rather it needs to should promote their quality. So classwork/ homework is regarded as an agreement between teachers and students in schools (smartclassroommanagement.com). Mostly teachers and parents have wrong conception that they want more homework; and students need to do it themselves. Parents want that their children need to engage throughout the hours they spend at home. It is wrong concept that the workshop has addressed in which homework needs to be easy and can be done by children themselves. The homework out of course is supposed to have relation or extension of the classwork.

Mostly the students have taken writing as homework and reading as no-homework. It has been thought that teachers and students have taken reading as cheap phenomena of reading process, or no homework. They excluded it from homework due to misunderstanding in which workshop has focused so much. We have found students weak in reading rather than writing so it becomes a matter of workshop innovation. They can write by copying the text that is related to hand art and reading is related to mind and heart. Unless they don't know the reading first writing only becomes a mechanical art for the students. The claim of NEGRP report about writing is against our understanding and experience. The report claimed that writing is quite poor than reading but our experience is vice-versa. So participants have given much emphasis in reading, as homework; it is the innovation of teachers from classroom. Teachers listed the point that they can assign some related topic as homework which is reachable for students. It means they can assign homework "with the tools to learn both within and outside the classroom" (Teemuangsai \& Meesook, 2017, p. 7)

The basic element of writing is reading first, though writing is considered 3 to 5 times effective than reading, the workshop recognizes reading more. Unless students don't get proficiency in reading he can't write well; so they 
go together. The motto of the workshop is to make all the students proficient in reading, writing and numeracy well. Homework management is quite necessary because more homework would be unnecessary burden and students wouldn't have interest to go to school. Smartclassroommanagement.com agrees that homework is as per the need of the students. It needs to be easy and parental involvement in homework doing is discarded unless they are interested. Mainly it creates problem in developing countries where parents are uneducated (MoE, Nepal, 2014). Thus homework needs to be in adequate amount, neither be it more nor less.

Students are supposed to be able to complete homework on time. There are 6 to 8 periods per day; if students have been given homework of all subjects it would be burden to them. So there is the need of cooperation or coordination among subject teachers. All written homework and classwork is also not good; so teachers can assign half reading homework. Sometimes they can assign project work that needs extra time and effort for the students. It needs teachers' follow up constantly which is the work of effective teacher. Learnersedge.com has taken homework as the continuation of school work that helps in revising classwork at home. It helps them in engaging rather than going to play with pals. However, homework in high amount is much counterproductive to the teacher as students would grow disgust against them.

Management of classwork and homework is an efficiency of the best teacher. The students need to do it systematically with good handwriting with $100 \%$ accuracy. So it's better to assign less but effective task to students. Or homework shouldn't be burden or a matter of headache for students. Homework is often best used as an extension of classwork. Teachers can plan in such a way so that a motivated student can complete all or most of the work can be done in class. Hence homework isn't a separate task rather than class continuation. It is just the extra time you are giving students to complete their classwork. In this way, being focused and working hard in classroom management, teacher can reduce the burden of homework of students.

\section{Conclusion}

The article has focused on the core aspect of classroom teaching probing into the depth of teaching learning process. Classroom is the center of innovative teaching learning process along with the students, teachers and administration to find out real problem and its solution. The abstract ideas of researchers and experts have been discussed, evaluated and implemented systematically by the participants. It is done by the participants, for the participants and of the participants. A practical approach of training is an asset of this workshop in which theoretical or emotional matters have been put aside. Rather than stating the problem only, the participants have pointed out the problems and locate their solution from the field. The trainer and trainee approach has been ruptured, hence superficial ideas have been given less importance, and a practical method is applied. The workshop has focused on 'what we do' rather than 'can be done' in classroom. It is more praxis based rather than theoretical approach of handling classroom by a teacher. Classroom problems have been pierced, solution is found, and finally illumination happens. 'Core teaching techniques' is the topic in which the limited classroom time has been divided into four parts and discussed extensively. Teachers have problems but they have been hiding in front of students and administration. This workshop has eliminated all those problems so that effective classroom management and teaching can happen. Most of the data have been collected from classroom including all the teachers. It is a great deal of teaching learning process that the participants have involved in decision making. Class concentration, teaching, reading and rereading, alternative punishment, and classwork/ homework are the topics of the workshop. It has been discussed in detail and solutions have been listed in points and discussed extensively. To make it authentic and reliable all sorts of research tools have been applied. These essential aspects of classroom can happen in a period which seems too much messy, but takes place in a systematic way. The lists of suggestions are directive to those teachers who have interest in innovative teaching learning process. It's truly an academic research that a teacher would be able to do in his teaching career. Both novice as well as experienced teachers can take it as new knowledge as well as remembrance of old ideas.

\section{References:}

Busienei, A. J. (2012). Alternative method to corporal punishment and their efficacy. Journal of emerging trends in educational research and policy studies , 3 (2), 155-161.

Andersson, J \& Lindkvist, J. (2000). Education in Nepal: A Study of Nepalese Teachers' Views on their School Situation. Institutionen för Pedagogik och Psykologi 58183 LINKÖPING

Day, C \& Simmons, P. Successful School Leadership; Education Development Trust. Highbridge House, 16-18 Duke Street, 2016. www.educationdevelopmenttrust.com

Prevention first. (2014). Classroom management strategies: classroom management resource guide. www.prevention.org.

MoE, Nepal. (2014). National early grade reading program (2014/15-2019/20. Kathmandu.

Hanover Research. (2017). Best Practices In Evaluating And Improving School Climate. www.hanoverresearch.com. 
IBRD. (2018). Learning to realize education's promise. The World Bank; 1818 H Street NW, Washington, DC 20433.

Jackson, L. C. (ed). Best Practices In Classroom Management; Christopher Dunbar College of Education; Michigan State University, University Outreach \& Engagement; 2004.

Johnson, D. (2001). Classroom behavoural strategies and interventions. Towards Inclusion: Tapping Hidden Strengths: Planning for Students Who Are Alcohol-Affected. Manitoba Education, Training and Youth. www.edu.gov.mb.ca.pdf.

Kohler-Evans, P. (2013). How to get wet without plunging in: Creative ways to start class. 10 effective classroom management techniques every faculty members should know. www.facultyfocus.com.

Korpershoek, H., Harms, T., de Boer, H., van Kuijk, M., \& Doolaard, S. (2014). Effective classroom management strategies and classroom management programs for educational practice: A meta-analysis of the effects of classroom management strategies and classroom management programs on students' academic, behavioural, emotional, and motivational outcomes. Groningen: RUG/GION.

Mathema, K. B. (2007). Crisis in Education and Future Challenges for Nepal. European Bulletin of Himalayan Research: p. 46-66.

MoES, Uganda. (2017). Positive discipline/ alternatives to coropral punishment training manual to end violence in school. MoES, Uganda.

OECD. (2016). OECD 2016 insights from the TALIS-PISA link data: Teaching strategies for instructional quality. www.oecd.org/edu/school/TALIS-PISA-LINK-teaching_strategies_brochure.pdf

Sieberer-Nagler, K. (2016). Effective Classroom-Management \& Positive Teaching. English Language Teaching, 9(1) doi:10.5539/elt.v9n1p163.

Sterling, M. L. (2003). Investigation in Practice: Setting the Stage for Transformative Learning. Fifth International Conference on transformative Learning. Teachers College Columbia University; New York.

Teemuangsai, S. \& Meesook,C. (2017). Thailand's classroom learning practices in secondary level: Are we ready for learning in the 21 st-Century? International Journal of Science and Technology Educational Research, 8(1), 1-12.

The Honor Level System. (2012). Discipline by Design: Serving classroom teachers and Students seeking a career in Education; http://www.honorlevel.com/x47.xml 9/15/2012

Wallis, N. C. (2003). Transformative Learning in a Classroom Context: Examining Habits of Mind as Curriculum; Fifth International Conference on transformative Learning. Teachers College Columbia University; New York.

\section{Websites}

https://www.dictionary.com/browse/workshop

https://www.learnersedge.com/blog/a-position-on-homework" https://www.learnersedge.com/blog/a-position-onhomework /

https://www.responsiveclassroom.org/homework/" https://www.responsiveclassroom.org/homework/ https://www.smartclassroommanagement.com/2010/07/31/effective-homework-plan-for-teachers-part-1/" https://www.smartclassroommanagement.com/2010/07/31/effective-homework-plan-for-teachers-part-1/ 